\title{
自己回帰モデルを用いたガス絶縁開閉装置(GIS) 部分放電検出法の開発
}

\begin{tabular}{|c|c|c|c|}
\hline 正 員 & 犬 & 島 & 浩 \\
\hline 員 & 栘出 & 井 & 健 \\
\hline 員 & 前 & 111 & 洋 \\
\hline
\end{tabular}

\section{Development of Partial Discharge Detection Method Using an Auto-Regressive Model in Gas Insulated Switchgears (GIS)}

Hiroshi Inujima, Member, Takeshi Masui, Member, Hiroshi Maekawa, Member (Mitsubishi Electric Corp.)

Gas insulated switchgears (GIS) are important equipment in electric-supply stations for that advanced techniques for safety and maintenance are required. So, we started developing a system that can automatically monitor and diagnose a GIS in service. This article focuses on some problems concerning insulating functions of GIS to discuss a method of signal processing for partial discharge detection and position identification. For sensors, potential detectors were installed on flanges of the GIS. Focusing on the potential fluctuations measured by these detectors, we created an auto-regressive model for potential fluctuation in a state without any partial discharge. This model is called a normal state model. Difference was found between potential fluctuations measured during partial discharge and those of the normal state model. The index of whiteness test method of the residual random process is a useful parameter for representing this difference and we found that using this allowed detection of partial discharge that could not be found at normal potential levels. These results mean bright prospects for manufacturing a monitoring system that can detect deterioration in GIS insulation with a high sensitivity in an early stage and that also operates on-line.

キーワード：GIS，部分放電，信号処理，異常診断，自己回㷌モデル，検定

\section{1.はじめに}

エネルギー源として電力へ依存する割合が個人の生 活敄会環境に扔いて增大し，電力の供給信頼性招よ び質的改善に対する要求がいっそう高まっている。ま た，高度情報社会への進展に上る稼働中の設備事故の 未然防止や，事故時の早期復旧に有効なシステムの要 請も高まっている。

こうした背景から，変電所設備の異常早期発見扔よ び保守技術は一つの重要な課題といえる。現在は変電 所設備の品質管理が徽底され信頼性が向上し，ほとん
ど故障しないという技術的背景があるうえに，特に重 要な系統は多重系で構成され万全の措置がなされてい る。また，定期点検などの実施により，設備の性能確 認扔よび予防保全がされて扔り，その効果も大きい。 それでも，運転中にシステムとして機能变失までには 至らないが，設備の故障発生証皆無ではない。トリッ ブなどが発生し機能票失するとシステム全体に重大な 影響を与える設備では，極力運転中の故障発生を回避 したいのは当然である。これらの故障の発生要因を早 期に検知し除去することで, 設備の信頼性向上, 稼働 率向上を図る必要があり，大きな要請がある。 
本論文ては, 変電所設備のなかで一つの重要な要素 設㣁であるガス絶縁開閉装置（GIS）を診断対象とし て選定している。GIS の内部異常は以下の監視対象に 大別できる。

(1) GIS 内部の絶縁異常

(2) 導体接触部の通電異常

（3）遮断器などの開閉異常

これらの異常診断手法は, 種々研究開発が進められ ているがこのなかで GIS 内部の絶緑異常に着目し た。これは万一絶縁破壤を伴う故障が発生すると, 復 旧に多くの時間を要し系統運用にも重大な影響を与え る特性を考慮した判断である。このことをふまえ， GIS の部分放電現象に診断対象を限定した。本論文で は，部分放電発生加ら絶緑破壞に至るまでにはある程 度時間が必要なことから, 少ない検出器で確実に部分 放電者高感度で早期に検知する豂断法と位置標定につ いて検討した。微少な部分放電検出が目的ではなく， あくまでも絶縁破壊阻止を目的としている。

\section{GIS の絶縁診断技術の現状 ${ }^{(1)}$}

GIS の部分放電を検出する手法として，電気的に検 出するものと，機械的に検出する方法が開発されてい る。このほか, 部分放電に起因する $\mathrm{SF}_{6}$ ガスの分解生 成物を㭘出する手法も報告されている。

〈2・1〉電気的部分放電検出 GIS 内部で部分放 電が発生すると，GIS 接地線に高周波電流が流れるの を検出する接地線電流法，絶縁スペーサに設置された 電極と高電圧導体間の静電容量を利用した手法が紹介 報告されている。GIS 中に部分放電が発生すると, 接 地構造物に急峻なパルス電流が流れる。このような高 周波電流が流れると接地棈造物の近傍にパルス波形に
近似した微少な電位差が発生する。これを直接測定す る手法も提案されている。また，GIS内部に発生した 部分放電パルスが GIS 内部を進行波として伝搬する と，絶縁取付け部などの電気的インピーダンス不連続 部分に電位差が発生する。これをとらえる手法も提案 されている。

$\langle 2 \cdot 2\rangle$ 光学的部分放電検出 部分放電に起因寸 る発光現象を検出する手法である。光電子增倍管に上 り，光学空をGISに設置して内部の放電検出やホト トランジス夕による㭘出法が提案されている。

〈2・3〉 その他部分放電検出部分放電に起因す る振動を計測する手法(2)である。GIS の外壁にマイ クロフォンや加速度計を取り付けて内部の振動を計測 し，信号は平均化処理を行って感度を向上させてい る。GIS内部の異物検出にも有効であるとの報告もさ れている(3)。また，GIS内部で長期間部分放電が発生 すると $\mathrm{SF}_{6}$ ガスが分解し， $\mathrm{SF}_{4}, \mathrm{SOF}_{2}, \mathrm{HF}$ が生じ る。これを検出するための簡易試薬やガスクロマトグ ラフィーを用いた装䈯が開発されている(1)。

\section{3. 部分放電実験}

図1に示す $550 \mathrm{kV}$ の GIS を用いて導体とタンクシ 一ス間にギャップを設けて，部分放電の模擬実験を奏 施した。部分放電を発生させたのは図1のS点であ り，放電電荷量忧 $500 \mathrm{pC}$ である。タンクフランジ部 分に電位を観測するための銅板を取り付けてある。こ れを部分放電センサと呼び，图 2 に概要を示す。部分

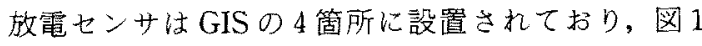
の $A, B, C, D$ に示した。

部分放電センサで検出された信号はデータ収集装置 とトリガリング装置に接続されている。定められたし

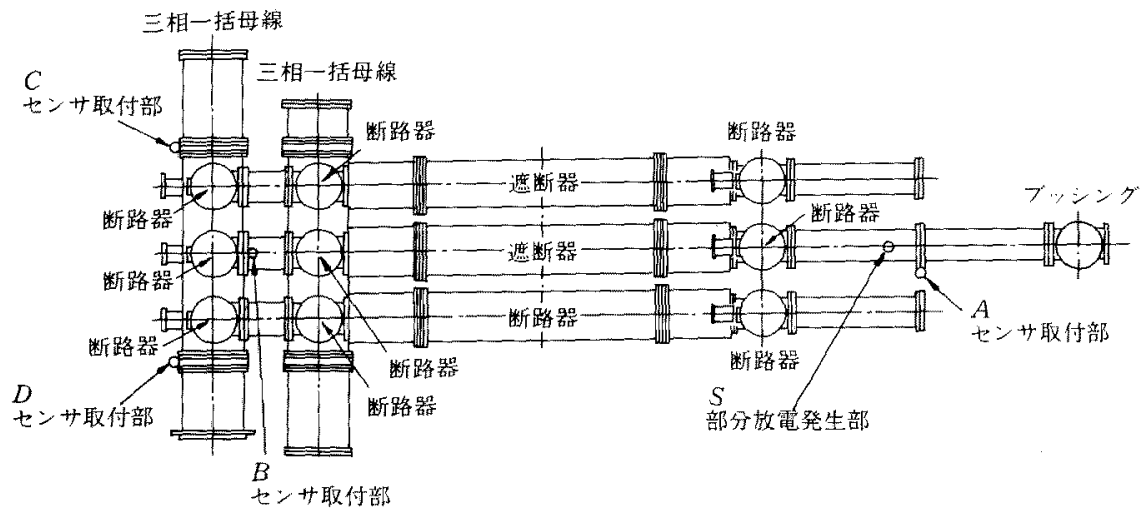

図 $1550 \mathrm{kV} \mathrm{GIS}$ 部分放電センサ取付け位置

Fig. 1. Mounting position of partial discharge sensors on $550 \mathrm{kV}$ GIS. 
きい值を超えると，データ収集装置にトリガをかけ， 前後のデータを記憶するよう設計されている。データ 収集装監のサンプリング時間は $1 \mathrm{~ns}$ で，トリガ前後 各々約 8,000 点の記憶が可能である。データ収集装置 は，計算機と接続されており，最終的にはフロッピー

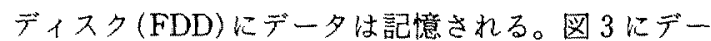
夕収集の概念図を示した。

部分放電発生時に括ける $A, B, C, D$ 各計测点

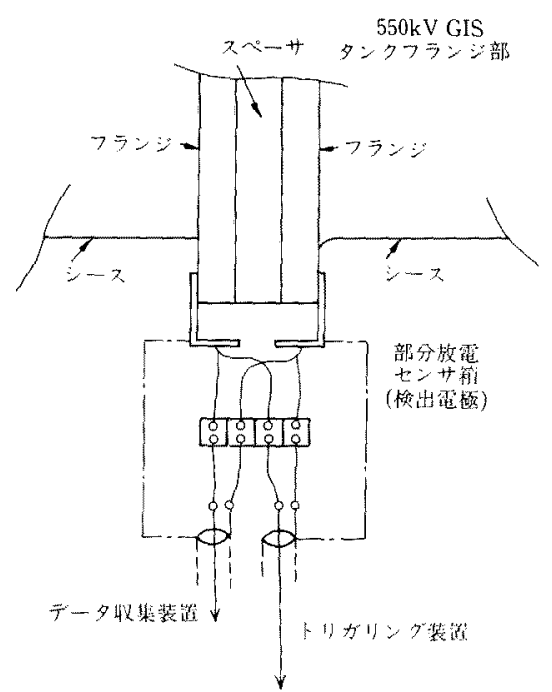

図 2 部分放電センけ概念図

Fig. 2. Schematic diagram of the partial discharge sensor.
の電位変動を図 4 に示す。部分放電発生点 $S$ から 0.8 $\mathrm{m}$ に没置された $A$ 点のセンサにおいては電位変動幅 が大きくバックグランドに対して 100 倍程度大きいこ とがわかる。一方， $S$ 点から $16.4 \mathrm{~m}$ 離れた $B$ 点での 検出器にはほとんど変化が現れず $0.2 \mu$ 遅れてバッ クグランドに対して 10 倍程度大きくなっていること がわかる。更に $S$ 点から $20.8 \mathrm{~m}$ 雄れている $C, D$ 点での険出器には枆とんど変化が見られない。

\section{4. 部分放電検出法}

図 1 のA点で観測された電位変動であれば単にし きい値で部分放電を検出可能である。一方， $B, C$,

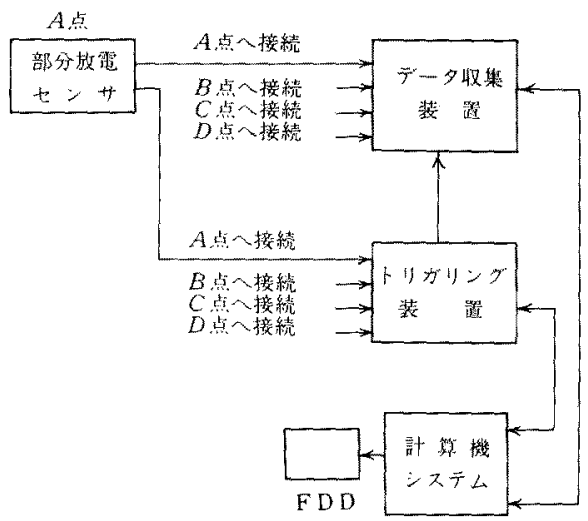

図 3 データ収集システムの概要

Fig. 3. Schematic diagram of the data aquisition system.

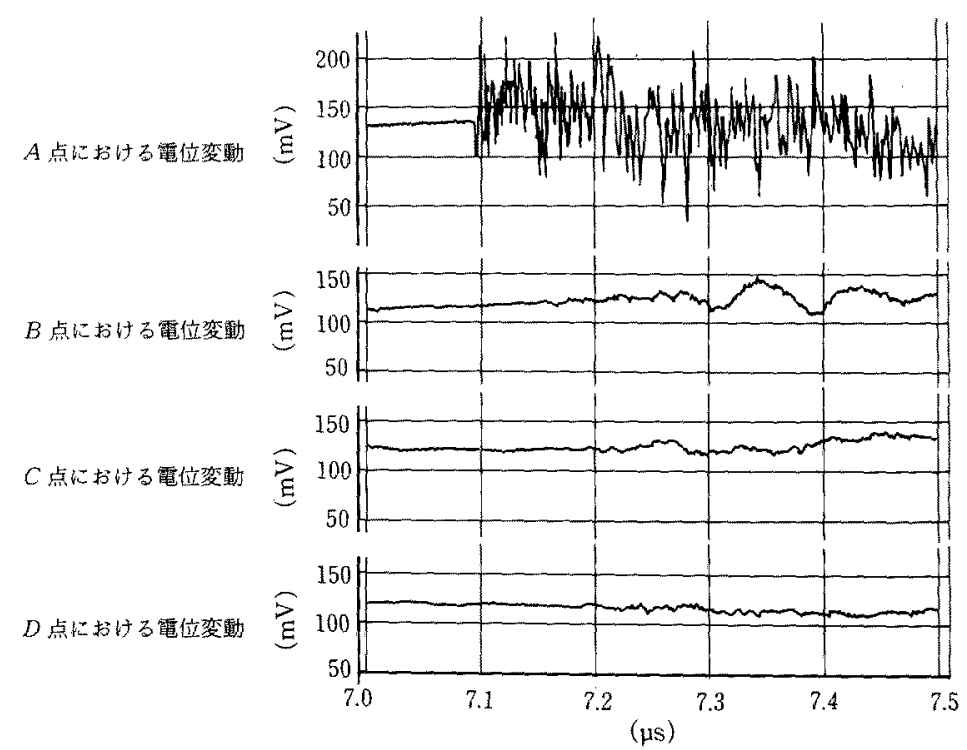

図 4 部分放電による電位変動

Fig. 4. Potential fuctuations under partial discharge condition. 


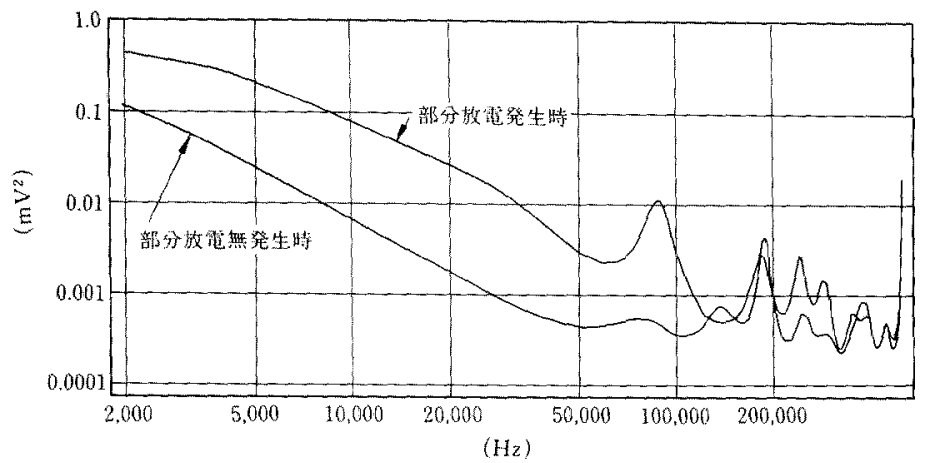

図 5 電位変動のパワースペクトル密度

Fig. 5. Power spectral densities of potential fluctuation.

$D$ 点で観測された電位変動は単純なレベルに関する しきい值では検出できない。そこで電位変動の統計的 な性質を検討し，部分放電が存在しない場合のバック グランドのモデルを作成し，これを基準とする検定問 題として取り扱うこととした。

$D$ 点で観測された部分放電なし（図 $407.1 \mu \mathrm{s}$ 前 1,000 点のデー夕）と部分放電発生時（図 4 の $7.2 \mu \mathrm{s}$ 後 1,000 点のデータ) のパワースペクトル密度(4)(5) 图5に示す。パワースペクトル密度の形状には, 部分 放電の有無による違いが見られ，放電発生時に 80 $\mathrm{kHz}$ 付近にピークが見られる。一方, 電位変動レべ 儿は部分放電発生時と部分放電なしの場合ほとんど変 化せず, $125 \mathrm{mV}$ 付近で推移しており，エネルギーレ ベルでの部分放電の区別は困難であることがわかる。

更に，部分放電がない場合の電位変動について再現 性を評価した。このために, 観測された電位変動の時 系列值 $y_{m}$ に対して (1)式で表現される自己回㷌モデ ル (Auto-Regressive モデル;ARモデル) ${ }^{(4)(5)}$ を導 入し，買なる時点でのARモデル推定結果の同一性 を評価した。これは，モデルの次数 $M$ とARパラメ 一夕 $\left(a_{1}, a_{2}, \cdots, a_{M}\right)$ の比較で実施可能である。

$$
\begin{aligned}
y_{m} & =\bar{y}_{m}+\varepsilon_{m} \\
& =\sum_{i=1}^{M} a_{i} y_{m-i}+\varepsilon_{m}
\end{aligned}
$$

$\bar{y}_{m}: y_{m}$ の予測值

ここて，ARパラメータは，正規性定常白色讙音を入 力とする定係数線形フィルタの係数と同義である。異 なる測定日に繰り返し測定した部分放電がない電位変 動の DFPE法により 20 と定められた(4)。最小二乗法によ りそれぞれのデー夕に対し求めた ARパラメータの 值结表1のようである。再現性の評価はモデルの安定 性も評価できる。すなわち, 部分放電がない場合, 観

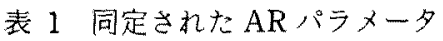

\begin{tabular}{|c|c|c|c|}
\hline AR パラータ & 夷験ケース I & 奏験ケース 2 & 実験ケース3 \\
\hline$a_{1}$ & -0.16 & -0.29 & -0.20 \\
\hline$a_{2}$ & -0.03 & -0.08 & -0.10 \\
\hline$a_{3}$ & -0.04 & 0.02 & 0.03 \\
\hline$a_{4}$ & -0.15 & -0.24 & -0.18 \\
\hline$a_{5}$ & -0.12 & -0.12 & -0.09 \\
\hline$a_{6}$ & -0.09 & -0.17 & -0.13 \\
\hline$a_{\gamma}$ & -0.08 & 0.04 & -0.00 \\
\hline$a_{8}$ & -0.09 & -0.08 & -0.04 \\
\hline$a_{9}$ & 0.08 & 0.00 & 0.00 \\
\hline$a_{00}$ & -0.15 & -0.15 & -0.13 \\
\hline$a_{11}$ & -0.18 & -0.08 & -0.05 \\
\hline$a_{12}$ & 0.06 & -0.06 & -0.05 \\
\hline$a_{13}$ & -0.00 & 0.13 & 0.07 \\
\hline$a_{14}$ & -0.06 & 0.00 & -0.03 \\
\hline$a_{15}$ & 0.05 & 0.07 & 0.02 \\
\hline$a_{38}$ & -0.03 & 0.01 & -0.10 \\
\hline$a_{17}$ & -0.01 & 0.04 & 0.01 \\
\hline$a_{18}$ & -0.08 & -0.09 & 0.03 \\
\hline$a_{14}$ & -0.02 & 0.05 & 0.04 \\
\hline$a_{20}$ & -0.08 & 0.01 & -0.06 \\
\hline
\end{tabular}

Table 1. Identified auto-regressive parameters.

楖されたデータから決定される自己回㷌モデルの次数 およびARパラメータが変化しないことを検証でき る。次数仙 3 回の測定でともに 20 次が最適という結 果が得られている。

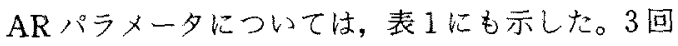
の測定で得られた $\mathrm{AR}$ パラメー夕值は，次数が大き くなるにつれて極端に大きくなったりせず，おおむ 权土0.2内のゼロ近傍の值で推移していることがわか る。これは過去の観湘値の影響が小さいことを示して 扔り，1/f雑音に近い性質を有していると考元られ る。以上の観点で，モデルの安定性はほほ保証されて いる。

電位変動波形はパワースペクトル密度にも示したよ うに白色ではない。正常時の電位変動波形の自己回帰 
モデルを作り，そのモデルによる予測值と観測対象で ある実測值の差（残差列）が白色である場合，観測対 象は正常と決めた電位変動と統計的に同一とみなせ る。すなわち，白色性がくずれた場合，正常時とは違 うことがわかる。その概念を図 6 に示す。

白色性の検定指標としては，残差列の自己相関関数 と時間軸で囲まれた面積で評価する。白色の場合，面 積は活涩 0 となり，相関が大きい潘ど面積が大きくな ることを利用している。

さて，安定なモデルが求められているから電位変動

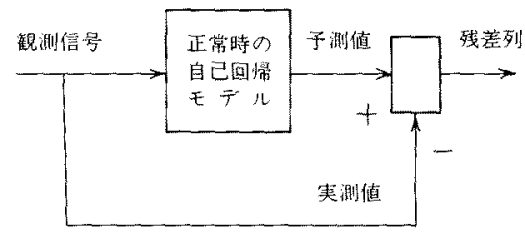

図 6 検出方法の概念

Fig. 6. Schematic diagram of the detection method.
を予測することができる。

$$
\bar{y}_{m}=a_{1} y_{m-1}+a_{2} y_{m-2}+\cdots+a_{M} y_{m-M}
$$

$\bar{y}_{m}: y_{m}$ の予測值

$M+1 \leqq m \leqq N, N:$ 全デー夕数

一方，実測值も観測できるこ加ら実測值と予測值の 差 $\varepsilon_{m}$ を求めることができ，これは通常残差と呼ばれ ている。

$$
\begin{aligned}
\varepsilon_{m}= & \widehat{y}_{m}-y_{m} \\
& (m=M+1, M+2, \cdots, N)
\end{aligned}
$$

この残差列が白色であれば，想定しているモデルで適 合していることを示している。ここで，白色性を評価 する指標として $\varepsilon_{m}$ の自己相関関数 $\phi_{k}(m)$ を計算す る。ここで,

$$
\begin{array}{r}
\phi_{k}(m)=\frac{1}{L} \sum_{h=0}^{L-1} \varepsilon_{m-h} \varepsilon_{m-h-k} \\
\left(k=1,2, \cdots, \tau_{\text {max }}\right)
\end{array}
$$

次に, 自己相関関数 $\phi_{k}(m)$ の時間軸と相関関数で囲 まれた面積を計算し，それを白色性検定指標とする。

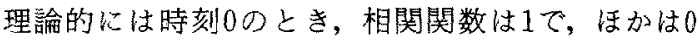

$A$ 点におけ古白色性椮定指標

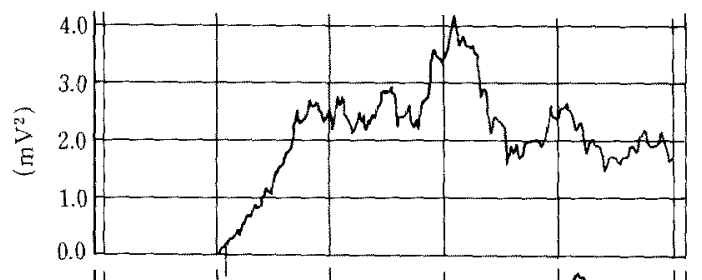

$B$ 点に扔ける白色性検定指標

C点における白色性检定指摽

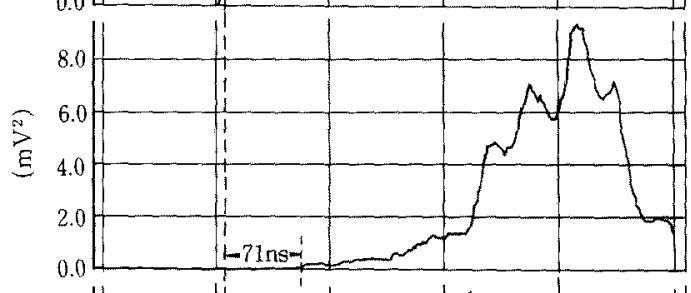

$D$ 点に拈ける白色性㭘定指標

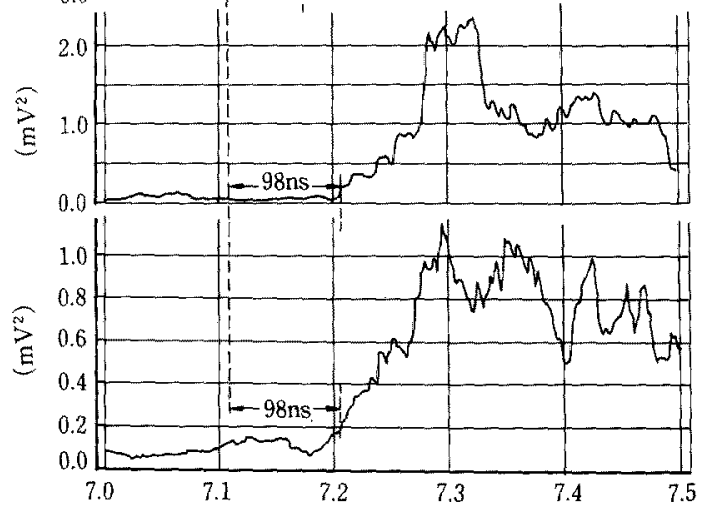

( $\mu \mathrm{s})$

図 7 部分放電における白色性検定指標

Fig. 7. Whiteness test method indexes under partial discharge condition. 
であるから面積が 0 に近いほど白色といえる。

$$
I(m)=\sum_{k=1}^{\tau_{\max }}\left|\phi_{k}(m)\right|^{2}
$$

実際には白色性検定指標はある分散をもっており，白 色であると判定する範囲を分散の 3 倍 $I_{\mathrm{ltm} t \mathrm{t}}$ などに設 定する。

$$
(O<) I(m) \leq I_{11 \mathrm{mit}}
$$

\section{5. 白色性検定指標の部分放電に対する感度 評価}

第 4 章の $(5)$ 式で導入した白色性検定指標の適用結 果を図 7 に示す。図1の $A, B, C, D$ 各点におい て測定された電位変動に適用した。この結果，きわめ て感度良く部分放電が検出されていることがわかる。 部分放電がない区間の白色性検定指標の分散值を計算 しその 3 倍を超えた時間を部分放電発生を検知した時 間とすると, $A, B, C, D$ 各点での検出時間を求め ることができる。また, 部分放電発生点 $S$ と $A, B$, $C, D$ 各点との距離は

$$
\begin{array}{lr}
S-A \text { 間 } & 0.8 \mathrm{~m} \\
S-B \text { 間 } & 16.4 \mathrm{~m} \\
S-C \text { 間 } & 20.8 \mathrm{~m} \\
S-D \text { 間 } & 20.8 \mathrm{~m}
\end{array}
$$

であり， $A$ 点で観測された時間と $B, C, D$ 各点で 観測された時間差は

$$
\begin{aligned}
& A-B \text { 間 } 71 \mathrm{~ns} \\
& A-C \text { 間 } 98 \mathrm{~ns} \\
& A-D \text { 間 } 98 \mathrm{~ns}
\end{aligned}
$$

である。距離と時間の比をそれぞれ計算すると

\section{距離 :}

$$
\frac{A-B \text { 間 }}{A-C \text { 間 }}=\frac{15.6 \mathrm{~m}}{20.0 \mathrm{~m}}=0.78
$$

時間：

$$
\frac{A-B \text { 間 }}{A-C \text { 間 }}=\frac{71 \mathrm{~ns}}{98 \mathrm{~ns}}=0.72
$$

とよく一致していることがわかる。ただし，伝搬速度 は $0.22 \mathrm{~m} / \mathrm{ns}$ 程度と評価され, 他の手法で測定され た $0.27 \mathrm{~m} / \mathrm{ns}$ 程度に比べ小さな值になっている(6)。 のように部分放電現象を感度良く検出でき, GISに設 置された検出器の位置と各々の時間差が計測できるこ とから, 部分放電場所の標定も可能であることがわか つた。

\section{6.おわりに}

雷などの自然現象や外部からの雑音など部分放電に 起因しない電位変動に対しては, 各計測点で観測され
た発生時間ベースとしたルールを設定して部分放電現 象との区別や，想定される雑音のみをあらかじめ除去 しておくなどの工夫(7) が必要であろう。

㭘出感度は部分放電の位置および放電電荷と検出器 の位置関係に依存する。本論文では，通常行われてい るレベルによるしきい值で, 検出できないほど減衰し た部分放電現象に起因する電位変動の変化の検出法を 報告した。また，GIS の構成に依存するが，実用的に は 4 点程度の検出点を設置することで，おおよその部 分放電位置の標定ができる可能性を示した。この意味 で高感度測定の実現がなされていると考えられる。

放電電荷量が小さくなると, 部分放電の位置が検出 器の近傍（数十七ンチメートル）ならば検出可能なこ とはわかっているが, 複数のフランジや断路器を経た 部分放電に起因する電位変動の伝搬に関しては, 今後 の検討課題である。検出可能な放電電荷量の評価を引 き続き検討する予定である。現在, 部分放電検出シス テムとして製作し，実際の開閉所で運用を開始してい る。これを通じてシステムの性能を向上させるととも に，電力の供給信頼性および質的改善に対する要求に 応之, 稼動 GIS の事故未然防止や, 事故時の早期復 旧に有効なシステムの確立を図る所存である。 (平成 4 年 8 月 24 日受付，同 4 年 11 月 19 日再受付)

\section{文献}

(1) 電力設備の運転中絶縁診断技術：電学技報（II 部）, No. 402 (平 4)

(2) N. Okuta, et al.: "Pattern recognition of vibration in metal enclosures of gas insulated equipment and its appiication", IEEE Trans. Power Apparatus Syst., PAS-100, No. 6 (1981)

(3) Y. Fujimoto, et al.: "Operation of an on-line substation diagnosis system", ibid., 3, No. 4 (1988)

（4）赤池・中川：ダイナミックシステムの統計的解析と制御（昭 47) サイエンス社

（5）得丸・添田・中海・秋月：計数・測定（昭 57）培風館

（6）電気協同研究，44，No. 3，27（1988）

（7）犬島：「信号処理によるノイズ除去はどこまで可能か」，工 レクトロニクス，37，No. 10，31 (平 4)

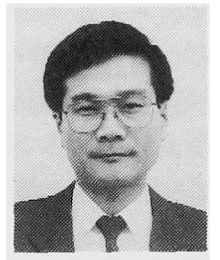

\section{犬 島＼cjkstart浩（正員）}

昭和 50 年 3 月北海道大学工学部電子 工学科卒業。同年 4 月三菱電機(株) 入 社。現在, 同産業システム研究所制御シ ステム開発部第1グループに所属。プラ ントの診断・制御に関する研究に従事。工学博士。平成 2 年電気学会論文賞受賞。日本原子力学会, 計測自動制御学 会，情報処理学会会員。 


\section{桝井健（正員）}

昭和 61 年 3 月徳島大学工学部電気工 学科卒業。同年 4 月三菱電機 (株) 入社。 伊丹製作所において, 変電機器監視シス テムの開発に従事。
前 川 洋 (正員)

昭和 47 年 3 月大阪府立大学大学院修 士課程修了。同年 4 月三菱電機(株)入 社。現在, 同伊丹製作所借勤務。主とし

て, 変電機器監視システムの開発に従

事。シミュレーション学会会員。 